\title{
OVERWEIGHT IN SCHOOLCHILDREN AND ASSOCIATION WITH PHYSICAL ACTIVITY AND PARENTAL HABITS
}

\author{
SOBREPESO EM ESCOLARESEASSOCIAÇÃO COM A PRÁTICADE ATIVIDADE FISICA EHÁBITOS PARENTAIS
}

SOBREPESO EN ESCOLARES YASOCIACIÓN CON LA PRÁCTICA DEACTIVIDAD FISICA Y HÁBITOS PARENTALES

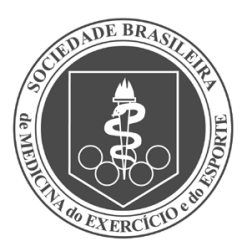

Original Article

ARTIGO ORIGINAL Artículo Original
Elena Sierra Palmeiro'

(Physical Education Professional)

Miguel Angel Gonzalez Valeiro' (Physical Education Professional)

Marian Fernandez Villarino ${ }^{2}$

(Physical Education Professional)

1. Universidade da Coruña, Faculdade de Ciências do Esporte e a Educação Física (UDC),

Oleiros, Spain.

2. Universidade De Vigo,

Faculdade de Ciências da

Educação e do Esporte,

Pontevedra, Spain

\section{Correspondence:}

Elena Sierra Palmeiro

Universidade de A Coruña,

Facultad de Ciencias del Deporte y la Educação Física (UDC). Avda. Che Ernesto Guevara 121.15179. Oleiros. A Coruña,

Spain.Elena.sierra@udc.es

\begin{abstract}
Introduction: Excess weight in childhood and adolescence is an important health problem that tends to persist in adulthood. Among the causes of this increase there appears to be a consensus on emphasizing physical activity as an excellent strategy to achieve better weight control, and on considering some models of parental practices essential for the acquisition of healthy habits in young people. Objective: To study the role of physical activity (undertaken by children and their parents) in the prevalence of overweight in Spanish schoolchildren. Methods: We studied 1687 schoolchildren aged between 13 and 17 years and 2335 mothers and fathers. The body mass index (BMI) of each child was calculated and information was collected on the physical activity level of the children and the parental physical activity level and BMI. Results: The schoolchildren analyzed have a higher prevalence of excess weight than the national average, significantly associated with age, sex, and excess weight of the mother, showing no significant association with the level of physical activity, but instead with the parental level of physical activity. Discussion: As predictive variables for excess weight in schoolchildren we found sex, age and excess weight of the mother. Conclusion: There is a prevalence of obesity and overweight in the sample of schoolchildren studied, and this is significantly associated with age rather than with physical activity. This prevalence is also significantly associated with the excess weight of the parents and with the level of physical activity of the father, which appears to confirm the influence of family characteristics and household physical activity in excess weight among schoolchildren. Level of Evidence I; Diagnostic studies - Investigating a diagnostic test.
\end{abstract}

Keywords: Obesity; Overweight; Physical activity; Healthy eating habits.

\section{RESUMO}

Introdução: O excesso de peso na infância e adolescência constitui-se em um importante problema de saúde que tende a persistir na idade adulta. Entre as causas desse aumento parece existir consenso em destacar a prática de atividade física como uma excelente estratégia para conseguir melhor controle do peso e em considerar alguns modelos de práticas parentais fundamentais para a aquisição de hábitos saudáveis nos jovens. Objetivo: Estudar o papel da atividade física própria e de seus pais na prevalência do excesso de peso em estudantes espanhóis. Métodos: Analisaram-se 1687 estudantes entre 13 e 17 anos e 2335 pais e mães. Calculou-se o índice de massa corporal (IMC) de cada criança e foram coletadas informações referentes ao nível de atividade física das crianças e ao nível de atividade física e IMC dos pais. Resultados: Os estudantes analisados apresentam prevalência de excesso de peso superior à média nacional associando-se significativamente com a idade, o sexo e o excesso de peso da mãe, não mostrando associação significativa com o nível da sua prática de atividade física e sim com a prática de atividade física dos pais. Discussão: Como variáveis preditivas para o excesso de peso nos estudantes encontramos o sexo, a idade e o excesso de peso da mãe. Conclusão: Há prevalência de obesidade e sobrepeso na amostra de estudantes analisada, e isso associa-se significativamente à idade e não à prática de atividade física. Essa prevalência também está associada significativamente ao excesso de peso dos pais e com o nivel de atividade física do pai, o que parece confirmar a influência das características familiares e sua prática de atividade física no excesso de peso escolar. Nível de Evidência l; Estudos diagnósticos - Pesquisa de um exame para diagnóstico.

Descritores: Obesidade; Sobrepeso; Atividade física; Hábitos alimentares saudáveis.

\section{RESUMEN}

Introducción: El exceso de peso en la infancia y la adolescencia se constituye en un importante problema de salud que tiende a persistir en la edad adulta. Entre las causas de ese aumento parece existir consenso en destacar la práctica de actividad física como una excelente estrategia para conseguir mejor control del peso y en considerar algunos modelos de prácticas parentales fundamentales para la adquisición de hábitos saludables en los jóvenes. Objetivo: Estudiar el papel de la actividad física propia y de sus padres en la prevalencia del exceso de peso en estudiantes españoles. Métodos: Se analizaron 1687 estudiantes entre 13 y 17 años y 2335 padres y madres. Se calculó el indice de masa corporal (IMC) de cada niño y fueron colectadas informaciones referentes al nivel de actividad física de los niños y al nivel de actividad física e IMC de los padres. Resultados: Los estudiantes analizados presentan prevalencia de exceso de peso superior al promedio nacional asociándose significativamente con la edad, el sexo y el exceso de peso de la madre, no mostrando asociación significativa con el nivel de su práctica de actividad física y sí 
con la práctica de actividad física de los padres. Discusión: Como variables predictivas para el exceso de peso en los estudiantes encontramos el sexo, la edad y el exceso de peso de la madre. Conclusión: Hay prevalencia de obesidad y sobrepeso en la muestra de estudiantes analizada, y eso se asocia significativamente a la edad y no a la práctica de actividad física. Esa prevalencia también está asociada significativamente al exceso de peso de los padres y con el nivel de actividad física del padre, lo que parece confirmar la influencia de las características familiares y su práctica de actividad física en el exceso de peso escolar. Nivel de Evidencia l; Estudios diagnósticos - Investigación de un examen para diagnóstico.

Descriptores: Obesidad; Sobrepeso; Actividad física; Hábitos alimenticios saludables.

\section{INTRODUCTION}

The World Health Organization (WHO) has warned ${ }^{1}$ that obesity is affecting an increasing proportion of the world's population, and the increase in the prevalence of overweight and obesity in children and adolescents is concerning. The IDEFICS Project ${ }^{2}$, conducted from 2006 to 2012, reported that one out of every five children has excess weight. Furthermore, there is a higher prevalence of childhood excess weight in southern European countries, with one of the highest rates being reported in Spain.

In Spanish children and adolescents, the prevalence of excess weight is $27.9 \%$ (18.3\% and $9.6 \%$, respectively). In the geographic region assessed in our study, the prevalence of obesity and overweight (34.6\%) is clearly more than the average Spanish prevalence, with one in three children having excess weight at increasingly younger ages. ${ }^{2}$

Obesity in childhood and adolescence leads to major complications $^{3}$, and the evidence clearly indicates that childhood obesity tends to persist into adulthood 4 . There are several causes of obesity; thus, the expression most used to define the origin of obesity is "obesogenic surroundings", which means that the origins of the current obesity epidemic are fundamentally social. ${ }^{5}$

There is a consensus on physical activity being an excellent strategy to achieve energy balance and weight control ${ }^{6,7}$ and to consider models of parental practices as fundamental for the acquisition of healthy habits in the young through physical activity. ${ }^{8,9}$

This study aimed to determine the prevalence of obesity and overweight in a population of Spanish schoolchildren and to analyze the effect of physical activity and family environment on excess weight.

\section{MATERIALS AND METHODS}

\section{Sample}

We conducted a descriptive and cross-sectional study with 22 educational centers that participated in the Center Sports Project within the Plan Proxecta of the Xunta de Galicia during 2013-2014. 10 A total of 1697 schoolchildren (873 girls and 824 boys) aged 13-17 years, 1078 fathers, and 1257 mothers participated in the study.

\section{Procedure}

The study followed the standards of the Helsinki Declaration of 1975 and was approved by the Research Ethics Committee of the University of A Coruña (UDC EC-10/2013). Participation was voluntary; the legal guardians signed an informed consent form; and confidentiality of the information obtained was guaranteed, consistent with the current laws. The registration forms and questionnaires were anonymized for the evaluation of data and dissemination of results.

The body mass index (BMI) of the students was calculated using the weight and height measurements. Weight was measured twice using a digital scale (model SECA 861) with an accuracy of $0.1 \mathrm{~kg}$. Height was measured twice, using a stadiometer (model SECA 222), to the nearest millimeter. The body weight status of the participating students (low weight, normal weight, overweight, and obesity) was then determined using the data from the study by Cole et al. ${ }^{11}$

The variables related to physical activity were calculated from a self-administered International Physical Activity Questionnaire (IPAQ) in the Spanish short version validated for adolescents (IPAQ-A). ${ }^{12}$ The IPAQ-A consists of five questions on the frequency, duration, and intensity of physical activity performed in the last 7 days, as well as time spent walking and time spent sitting during a weekday.

According to these data, the students were categorized into three groups according to the number of hours of weekly physical activity proposed by the WHO: very slightly or not active (between 0 and 7 hours), active (between 7 and 10 hours), and very active (more than 10 hours). To assess the effect of the family environment, the parents' BMI and their physical activity levels were assessed through the IPAQ using self-reported data.

\section{Statistical analysis}

A descriptive analysis of the variables was performed to evaluate the characteristics of the sample studied. The chi-square test was used to study the relationship between variables. The association between the variables was modeled through multinomial logistic regression. As part of this last analysis, the adjusted odds ratios (ORs) were calculated with 95\% confidence intervals (Cls). The significance level was $p<0.05$. All analyses were performed with the SPSS statistical analysis package version 22.0.

\section{RESULTS}

Differences in physical characteristics according to sex were significant only for weight ( $p=0.023)$, height ( $p=0.003)$, and BMI $(p=0.045)$. The prevalence of excess weight among the students was $41.2 \%$ (overweight 27.6\% and obesity $13.6 \%$ ) (Table 1), with a slightly higher but non-significant prevalence in boys (41.8\%) than in girls (40.5\%).

Regarding physical activity (Table 1), only $33.1 \%$ of the sample could be classified as active or very active according to the hours dedicated to some physical activity, in contrast to $66.9 \%$ categorized as slightly or very slightly active. Male schoolchildren were significantly more active (44\%) than female schoolchildren (22.8\%). The proportion of active schoolchildren decreased significantly with age, from $35.4 \%$ at 13 years to $23.9 \%$ at 17 . Schoolchildren tended to overestimate their level of physical activity, as $64.4 \%$ considered themselves active or very active compared with $33.1 \%$ in real terms.

Table 2 shows a significant increase in the prevalence of excess weight with age, which was greater in boys than in girls (Table 2).

There were no significant associations between BMI and physical activity level in either the total number of students or in either sex. These data appear contradictory (Table 1) as 49.6\% of children with overweight and $23.9 \%$ of children with obesity were found in the group of active or very active participants. Girls with excess weight were less active than boys. 
The relationships between the BMI of the students and the BMI of the father and the mother (Table 3) were significant overall and by sex.

The relationship of students' BMI with the level of parental physical activity (Table 3) was significant only for the fathers and not for the mothers. The physical activity level of the schoolchildren was significantly associated only with the physical activity of the mothers and not with that of both parents together (Table 4).

The predictive variables for excess weight (obesity and overweight) in the total number of schoolchildren analyzed were sex $(\mathrm{OR}=0.83$ $[95 \% \mathrm{Cl}=0.73-0.95], p<0.009)$, age $(\mathrm{OR}=1.32[95 \% \mathrm{Cl}=1.13-1.53], p<$ $0.001)$, and excess weight of the mother $(\mathrm{OR}=1.95$ [95\% Cl = 1.44-2.63], $p<0.001$ ). The other variables studied (physical activity of children, parental physical activity, and excess weight of the father) did not correlate significantly with excess weight of children. Age $(\mathrm{OR}=1.38[95 \% \mathrm{Cl}=1.11-1.72]$, $p<0.003)$ and physical activity $(\mathrm{OR}=0.75[95 \% \mathrm{Cl}=0.61-0.92]$, $p<0.007)$ were also predictive variables in boys, and age $(\mathrm{OR}=1.29[95 \%$ $\mathrm{Cl}=1.06-1.58], p<0.01)$ and excess weight of the mother $(\mathrm{OR}=3.23[95 \%$ $\mathrm{Cl}=2.13-4.91], p<0.000$ ) are predictive variables in female schoolchildren.

Table 1. Descriptive data, weight prevalence, and level of physical activity in the sample.

\begin{tabular}{|c|c|c|c|}
\hline & $\begin{array}{c}\text { Total } \\
\mathrm{n}=1697\end{array}$ & $\begin{array}{c}\text { Boys } \\
n=873\end{array}$ & $\begin{array}{c}\text { Girls } \\
n=824\end{array}$ \\
\hline \multicolumn{4}{|c|}{ Physical characteristics, mean \pm SD } \\
\hline Age (years) & $14.28 \pm 1.06$ & $14.29 \pm 1.07$ & $14.27 \pm 1.05$ \\
\hline Weight (kg) & $54.34 \pm 11.41$ & $53.01 \pm 1.60$ & $55.73 \pm 12.21$ \\
\hline Height (m) & $1.62 \pm 0.09$ & $1.60 \pm 0.07$ & $1.64 \pm 0.10$ \\
\hline \multicolumn{4}{|l|}{$\operatorname{BMI}\left(\mathrm{kg} / \mathrm{m}^{2}\right)$} \\
\hline Children & $20.52 \pm 3.71$ & $20.59 \pm 4.05$ & $20.45 \pm 3.31$ \\
\hline ...Parents & --- & $27.01 \pm 3.63$ & $25.07 \pm 4.008$ \\
\hline \multicolumn{4}{|c|}{ Weight prevalence (\%) } \\
\hline Low birth weight & 24.0 & 24.4 & 23.5 \\
\hline Normal & 34.8 & 35.0 & 34.7 \\
\hline Overweight & 27.6 & 27.0 & 28.3 \\
\hline Obesity & 13.6 & 13.5 & 13.5 \\
\hline \multicolumn{4}{|c|}{ Level of physical activity (\%) } \\
\hline Slightly active & 66.9 & 77.3 & 55.9 \\
\hline Active & 16.7 & 13.6 & 20.0 \\
\hline Very active & 16.4 & 9.2 & 24.0 \\
\hline \multicolumn{4}{|c|}{$\begin{array}{c}\text { Perception of physical } \\
\text { activity level (\%) }\end{array}$} \\
\hline Slightly active & 37.3 & 37.6 & 33.6 \\
\hline Active & 34.4 & 34.4 & 34.4 \\
\hline Very active & 30.0 & 19.5 & 40.0 \\
\hline
\end{tabular}

SD: standard deviation; BMl: body mass index.

Table 2. Prevalence of excess weight (overweight plus obesity) by sex and age.

\begin{tabular}{c|c|c|c}
\hline \multirow{2}{*}{} & \multicolumn{3}{|c}{ Prevalence of excess weight (\%) } \\
\cline { 2 - 4 } & $\begin{array}{c}\text { Global } \\
\mathbf{n = 1 6 9 7}\end{array}$ & $\begin{array}{c}\text { Female } \\
\mathbf{n = 8 7 3}\end{array}$ & $\begin{array}{c}\text { Male } \\
\mathbf{n = 8 2 4}\end{array}$ \\
\hline p-value & $0.000^{* *}$ & $0.021^{*}$ & $0.001^{*}$ \\
\hline Age (years) & & & 34.2 \\
\hline 13 & 33.2 & 32.3 & 37.1 \\
\hline 14 & 38.1 & 39.2 & 44.5 \\
\hline 15 & 45.5 & 43.8 & 55.9 \\
\hline 16 & 54.2 & 54.1 & 76.2 \\
\hline 17 & 65.8 & 55.0 & \\
\hline
\end{tabular}

Table 3. Prevalence of excess weight with parental BMI and activity level.

\begin{tabular}{|c|c|c|c|c|c|c|}
\hline & \multicolumn{6}{|c|}{ Prevalence of excess weight (\%) } \\
\hline & \multicolumn{2}{|c|}{ Total } & \multicolumn{2}{|c|}{ Female } & \multicolumn{2}{|c|}{ Male } \\
\hline & Overweight & Obesity & Overweight & Obesity & Overweight & Obesity \\
\hline \multicolumn{7}{|c|}{ 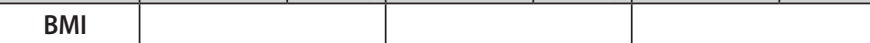 } \\
\hline \multicolumn{7}{|l|}{ Father } \\
\hline$p$-value & \multicolumn{2}{|c|}{$0.000^{* *}$} & \multicolumn{2}{|c|}{$0.003^{*}$} & \multicolumn{2}{|c|}{$0.001^{*}$} \\
\hline Overweight & 45.3 & 34.1 & 47.5 & 24.3 & 42.9 & 33.3 \\
\hline Obesity & 25.6 & 36.6 & 24.6 & 31.9 & 26.8 & 39.7 \\
\hline \multicolumn{7}{|l|}{ Mother } \\
\hline$p$-value & \multicolumn{2}{|c|}{$0.001^{*}$} & \multicolumn{2}{|c|}{$0.001^{*}$} & \multicolumn{2}{|c|}{$0.000^{* *}$} \\
\hline Overweight & 37.5 & 9.3 & 30.1 & 34.8 & 30.1 & 34.8 \\
\hline Obesity & 35.0 & 26.4 & 8.8 & 23.2 & 8.8 & 23.2 \\
\hline \multicolumn{7}{|l|}{$\begin{array}{l}\text { Physical } \\
\text { activity }\end{array}$} \\
\hline \multicolumn{7}{|l|}{ Father } \\
\hline$p$-value & \multicolumn{2}{|c|}{$0.015^{*}$} & \multicolumn{2}{|c|}{$0.017^{*}$} & \multicolumn{2}{|c|}{0.322} \\
\hline Active & 25.7 & 11.2 & 26.3 & 9.6 & 25.1 & 12.8 \\
\hline Not active & 26.7 & 15.2 & 25.6 & 14.2 & 28.2 & 16.5 \\
\hline \multicolumn{7}{|l|}{ Mother } \\
\hline$p$-value & \multicolumn{2}{|c|}{0.209} & \multicolumn{2}{|c|}{0.323} & \multicolumn{2}{|c|}{0.293} \\
\hline Active & 27.7 & 12.0 & 28.4 & 12.1 & 29.8 & 15.2 \\
\hline Not active & 26.6 & 14.2 & 23.8 & 13.3 & 26.9 & 11.9 \\
\hline
\end{tabular}

Table 4. Physical activity level in relation to parental physical activity level.

\begin{tabular}{|c|c|c|c|c|c|c|}
\hline \multirow{3}{*}{$\begin{array}{l}\text { Parental physical } \\
\text { activity level }\end{array}$} & \multicolumn{6}{|c|}{ Activity level prevalence (\%) } \\
\hline & \multicolumn{2}{|c|}{ Total } & \multicolumn{2}{|c|}{ Female } & \multicolumn{2}{|c|}{ Male } \\
\hline & Not active & Active & Not active & Active & Not active & Active \\
\hline \multicolumn{7}{|l|}{ Mother } \\
\hline$p$-value & \multicolumn{2}{|c|}{$0.017^{*}$} & \multicolumn{2}{|c|}{$0.023^{*}$} & \multicolumn{2}{|c|}{0.161} \\
\hline Very slightly active & 32.2 & 27.6 & 41.4 & 37.4 & 21.4 & 17.4 \\
\hline Slightly active & 36.2 & 38.7 & 36.3 & 38.1 & 36.2 & 39.4 \\
\hline Active & 16.9 & 16.5 & 15.5 & 12.5 & 18.5 & 20.8 \\
\hline Very active & 14.7 & 17.2 & 6.8 & 12.0 & 23.9 & 22.4 \\
\hline \multicolumn{7}{|l|}{ Father } \\
\hline p-value & \multicolumn{2}{|c|}{0.364} & \multicolumn{2}{|c|}{0.133} & \multicolumn{2}{|c|}{0.597} \\
\hline Very slightly active & 32.9 & 25.6 & 43.8 & 35.1 & 20.7 & 14.7 \\
\hline Slightly active & 36.5 & 36.6 & 37.5 & 35.9 & 35.4 & 38.5 \\
\hline Active & 15.3 & 18.6 & 10.5 & 18.9 & 20.7 & 18.3 \\
\hline Very active & 15.3 & 19.2 & 8.2 & 11.0 & 23.2 & 28.6 \\
\hline
\end{tabular}

\section{DISCUSSION}

The prevalence of excess weight in the population studied (41.1\%) was much higher than that reported previously. ${ }^{7}$ The prevalence was higher than the $25.5 \%$ reported for Spanish children aged between 14 and 17 years, ${ }^{13} 20.9 \%$ for secondary students in southern Spain, ${ }^{14} 26.2 \%$ for adolescents from the Canary Islands, 31.9\% for children and adolescents in southeastern Spain, 25.5\% for Brazilian adolescents, ${ }^{15}$ and 29.9\% for Mexican adolescents. ${ }^{16}$ However, the prevalence in the present study was slightly lower than the $57.5 \%$ prevalence reported in a population of 13-year-old schoolchildren from Chile ${ }^{17}$ and the $43 \%$ prevalence of obesity and overweight in Mexican children reported by Safdie et al. ${ }^{18}$ Another study, conducted in the same region where the present study was performed, reported a $38.15 \%$ prevalence of excess weight, ${ }^{19} \mathrm{a}$ discrepancy that may be attributed to the time duration between the studies. The schoolchildren studied had a higher prevalence of excess weight than those in other areas of Spain, which coincides with published data in adults in the same areas.

Most studies report an increase in excess weight with age, similar to our data. The higher prevalence observed in boys than in girls is common 
in Spain and other similar populations, such as in Mexico, ${ }^{17}$ although there have been reports of a higher or similar prevalence in girls. ${ }^{20}$ This may correspond to the influence of individual determinants related to the onset of puberty, a time of major changes in BMI.

Regarding physical activity, the proportion of active students in our study (32\%) is similar to that presented by Hallal et al., ${ }^{21}$ who reported that $80.3 \%$ of the children and adolescents had less than 60 minutes of moderate to vigorous physical activity per day, but is considerably less than the $71.5 \%$ of active or very active Spanish children reported previously ${ }^{22}$, probably because of differences in the criteria used to classify physical activity. Greca et al. report similar data in Brazilian students, with $13.4 \%$ being active and $86.5 \%$ being inactive.

Boys are more active than girls, in line with the Spanish, Brazilian, Mexican, American, and European studies ${ }^{24}$. Male predominance may be due to the different role models in our society that restrict girls and women from participating in sports. Although there has been some progress, these results highlight the importance of encouraging more participation in sports activities among young girls.

The relationship between BMI and physical activity was not significant, and the results do not agree in general with those found in the literature suggesting that the prevalence of overweight and obesity was lower among children and adolescents with a better level of physical condition or those who participate in sports activities several days per week, compared with more sedentary children. ${ }^{25}$ Multifactorial and direct intervention studies also report that a decrease in BMl is associated with an increase in physical activity.

In our study, $30.3 \%$ of the children with excess weight were active or very active compared with $36.4 \%$ of the children with normal weight. Several studies have reported significant differences in the number of hours of physical activity per week and the prevalence of obesity. Villagran et al. ${ }^{26}$ obtained conflicting results, similar to our results. We believe that the diagnosis of overweight using only BMI in children is not precise and may be limited by the inability to differentiate between fat mass and lean mass; for example, a child athlete without a high fat percentage can be classified as overweight or a child having a high fat percentage can be classified as having a suitable weight. Another factor to be taken into account but not analyzed in this study is the increase of sedentary habits that can counteract the physical activity.

We should also consider that BMI does not discriminate with respect to the distribution of body fat. Thus, it is recommended to use waist circumference measured at the abdominal level as an anthropometric parameter to measure central fat because of its possible relation with the metabolic syndrome. ${ }^{27}$

We emphasize that the association between the BMI of the students and the perception of their level of physical activity was significant (Table 3). No published data have been found that allow a discussion or explanation for this apparent inconsistency.
A correlation between the parents' and child's BMI was found, and the proportion of students with excess weight was higher among those whose father (39.9\%) and especially mother (49.3\%) had excess weight. Villagrán et al. ${ }^{27}$ reported that in overweight children, $68.6 \%$ of the parents and $38 \%$ of the mothers were also overweight. A more significant association was noted with the BMI of the mother. We also believe that, in addition to genetics, the lifestyles of both parents, especially the mother and her role in the child's nutritional habits may explain these findings.

Only a few studies have reported a relationship between the parents' physical activity level and the BMI of schoolchildren compared with studies that reported a positive relationship between the parents' physical activity and that of their children. In our study, we found a significant relationship between overweight in children and the physical activity level of the father. A similar relationship was also found by Piéron and Ruiz-Juan, ${ }^{8}$ who noted that this may be because the father is the most active parental model. The variables we identified that are predictive for excess weight among schoolchildren confirm the results obtained in previous studies. ${ }^{27,28}$

\section{CONCLUSION}

There was a high prevalence of obesity and overweight in the sample of schoolchildren studied, which was associated significantly with age and not with physical activity. The obesity and overweight in children were also significantly associated with excess weight of the parents and with the physical activity level of the father, which seems to confirm the influence of family characteristics and their physical activity on schoolchildren's excess weight. We can conclude that in order to understand excess weight in children, it is important to have a model that takes into account the most relevant variables of the current obesogenic lifestyle, such as physical activity, diet, and family habits. Studies such as ours allow us to establish that specific strategies for preventing overweight must involve not only the individual subject but also the social and institutional environment in which children coexist and develop. The limitations of the study are related to sample size, methods used for measuring variables, and exclusion of variables of interest. The cross-sectional design makes it difficult to establish cause-and-effect relationships, and therefore, longitudinal studies should be conducted in the future. Finally, data collection through a questionnaire may have resulted in various biases.

This work is integrated into a broader research whose objective is to analyze the habits of physical activity, health and lifestyle of Galician schoolchildren. This project has, among other objectives, that the participating centers be units that promote healthy physical activity. As a first step of this evaluation, an updated study is carried out on the prevalence of excess weight and its relationship with other variables that may have direct incidence, highlighting the practice of physical activity and variables related to parents.

All authors declare no potential conflict of interest related to this article

AUTHORS' CONTRIBUTIONS: Each author made significant individual contributions to this manuscript: ESP (0000-0002-1983-3497)*: creation of the research project, writing, data analysis and interpretation and review of the document, and final approval of the version to be published. She was also responsible for ensuring the integrity or accuracy of the excerpts taken from research sources. MAGV (0000-0002-3993-8069)*: creation of the research project, data collection, critical review of the document and final approval of the version to be published. He was also responsible for ensuring the integrity or accuracy of the excerpts taken from research sources. MFV (0000-0002-2466-8940*) data analysis and interpretation, critical review of the document and final approval of the version to be published. She was also responsible for ensuring the integrity or accuracy of the excerpts taken from research sources.. *ORCID (Open Researcher and Contributor ID).

\section{REFERENCES}

1. World Health Organization. Informe sobre la situación mundial de las enfermedades no transmitibles 2014. Ginebra: WHO: 2014.

2. Ahrens W, Moreno LA, Pigeot I. Obesity determinants and reference standards for health parameters in pre-adolescent European children: results from the IDEFICS study. Int J Obes (Lond). 2014;38(Suppl 2):2-3.
3. Speiser PW, Rudolf MC, Anhalt H, Camacho-Hubner C, Chiarelli F, Eliakim A, et al. Childhood obesity. J Clin Endocrinol Metab 2005;90(3): 1871-87.

4. McCambridge TM, Bernhardt DT, Brenner JS, Congeni JA, Gomez JE, Gregory AJM, et al. Active Healthy Living: prevention of childhood obesity through physical activity. Pediatrics. 2006;1 17(5):1834-42 
5. Wang LY, Chyen D, Lee S, Lowry R. The association between body mass index in adolescence and obesity in adulthood. J Adolesc Health 2008;42(5):512-8

6. Consellería de Sanidad. XERMOLA: Plan para la prevención de la obesidad infantil en Galicia. Santiago de Compostela: Xunta de Galicia 2014.

7. Ministerio de Sanidad, Servicios Sociales e Igualdad. Agencia Española de Seguridad Alimentaria y Nutrición. Estudio de vigilancia del crecimiento Aladino. Madrid: Estrategia Naos; 2013.

8. Piéron M, Ruiz-Juan F. Influence of family environment and peers in physical activity habits of youth people. Rev Inter Med Cienc Activ Fís Deporte. 2013;13(51):525-49.

9. Sanz-Arazuri E, Ponce-de-León-Elizondo A, Valdemoros-San-Emeterio MÁ. Parental predictors of physical inactivity in Spanish adolescents. J Sports Sci Med. 2012;11(1):95-101.

10. Xunta de Galicia. Consellería de Cultura, Educación e Ordenación Universitaria. Plan Proxecta. 2015. [access in 2015, abril, 15] Available in: http://www.edu.xunta.es/portal/planproxecta

11. Cole T, Bellizzi MC, Flegal KM, Dietz WH. Establishing a Standard definition for child overweight and obesity worldwide: international survey. BMJ. 2000;320(7244):1240-3.

12. Delgado M, Tercedor P, Soto VM. Traducción de la Guía para el procesamiento de datos y análisis de Cuestionario Internacional de Actividad Física (IPAQ). Versiones corta y larga. Universidad de Granada Junta de Andalucía. 2005. [accces in: 2015, amrzo]. Avaliable en http://www.juntadeandalucia.es/ salud/sites/csalud/galerias/documentos/p_4_p_2_promocion_de_la_salud/actividad_fisica_alimentacion_equilibrada/IPAQ_Guia_Traducida.pdf

13. Sánchez-Cruz JJ, Jiménez-Moleón JJ, Fernández-Quesada F, Sánchez MJ. Prevalencia de obesidad infantil y juvenil en España en 2012. Rev Esp Cardiol (Engl Ed). 2013;66(5):371-6.

14. Lima-Serrano M, Guerra-Martín MD, Lima-Rodríguez JS. Estilos de vida y factores asociados a la alimentación y la actividad física en adolescentes. Nutr Hosp. 2015;32(6):2838-47.

15. Henriquez Sánchez P, Doreste Alonso J, Laínez Sevillano P, Estévez González MD, Iglesias Valle M, López Martin G, et al. Prevalencia de obesidad y sobrepeso en adolescentes canarios. Relación con el desayuno y la actividad física. Med Clin (Barc). 2008;130(16):606-10

16. Bloch KV, Klein CH, Szklo M, Kuschnir MCC, Abreu GA, Burufaldi LA, et al. ERICA: prevalence of hypertension and obesity in Brazilian adolescents. Rev Saúde Pública. 2016;50(Suppl 1):1-9.

17. Morales-Ruán MC, Hernández-Prado B, Gómez-Acosta LM, Shamah-Levy T, Cuevas-Nasu L. Obesidad, sobrepeso, tiempo frente a la pantalla y actividad física en adolescentes mexicanos. Salud Publica Mex. 2009:51(Suppl 4):613-20.

18. Delgado Floody P, Caamaño Navarrete F, Cresp Barría M, Osorio Poblete A, Cofré Lizama A. Estado nutricional en escolares y su asociación con los niveles de condición física y los factores de riesgo cardiovascular. Nutr Hosp. 2015:32(3):1036-41.

19. Safdie M, Jennings-Aburto N, Lévesque L, Janssen I, Campirano-Núñez F, López-Olmedo N et al. Impact of a school-based intervention program on obesity risk factors in Mexican children. Salud Publica Mex. 2013;(Suppl 3):347-87.

20. Vázquez FL, Díaz O, Pomar C. Prevalence of overweight and obesity among preadolescent schoolchildren in Galicia. Child Care Health Dev. 2010;36(3):392-5.

21. Martínez-Gómez D, Welk GJ, Calle ME, Marcos A, Veiga OL, AFINOS Study Group. Preliminary evidence of physical activity levels measured by accelerometer in Spanish adolescents; The AFINOS Study. Nutr Hosp. 2009;24(2):226-32

22. Hallal PC, Andersen LB, Bull FC, Guthold R, Haskell W, Ekelund U, et al. Global physical activity levels: surveillance progress, pitfalls, and prospects. Lancet. 2012;380(9838):247-57.

23. Cano A, Pérez I, Casares I Y Alberola S. Determinantes del nivel de actividad física en escolares y adolescentes: estudio OPACA. An Pediatr (Barc). 2011;74(1):15-24.

24. Greca JPA, Arrudaa GA, Coledama DC, Pires Junior R, Teixeira M Oliveira AR. Student and parental perception about physical activity in children and adolescents. Rev Andal Med Deporte. 2016;9(1):12-6.

25. Borraccino A, Lemma P, lannotti RJ, Zambon A, Dalmasso P, Lazzeri G, et al. Socioeconomic effects on meeting physical activity guidelines: comparisons among 32 countries. Med Sci Sports Exerc 2009;41(4):749-56.

26. Villagrán Pérez S, Rodríguez-Martín A, Novalbos Ruiz JP, Martínez Nieto JM, Lechuga Campoy JL. Hábitos y estilos de vida modificables en niños con sobrepeso y obesidad. Nutr Hosp. 2010;25(5):823-31.

27. Savva SC, Tornaritis M, Sava ME, Kourides Y, Panagi A, Silikiotou N, et al. Waist circumference and waist to height ratio are better predictor of cardiovascular disease risk factors in children than body mass index. Int J Obes Relat Metab Disord. 2000;24(11):1453-8.

28. Gálvez Casas A, Rodríguez García PL, Rosa Guillamón A, García-Cantó E, Pérez Soto JJ, Tárraga Marcos ML, et al. Nivel de condición física y su relación con el estatus de peso corporal en escolares. Nut Hosp. 2014;31(1):393-400. 